\title{
PERBEDAAN KUALITAS PERSAHABATAN MAHASISWA DITINJAU DARI MEDIA KOMUNIKASI
}

\author{
Nessa P. D. Suyono \\ Sumedi P. Nugraha

\begin{abstract}
Fakultas Psikologi dan Ilmu Sosial Budaya Universitas Islam Indonesia Yogyakarta Email: snugraha@gmail.com
\end{abstract}

\begin{abstract}
The purpose of this research was to compare the friendship quality of university students based on face to face and mediated communication. This study involved 91 students majoring in Psychology at the Universitas Islam Indonesia (sixty five females and twenty six males). Friendship Quality Scale was used to collect the data. This instrument was developed by the researchers based on Asher and Parker (1993) friendship quality aspects. Paired Sample Test technique was used to analyze the data. The researchers used the Statistical Product and Service Solution (SPSS), Windows version 12.0. as a tool to calculate the data. Results have shown that quality of friendship based on face to face communication (mean score $=171,5165$ ) has higher score than quality of friendship based on mediated communication (mean score $=160,0989$ ), $t=7,055, p=$ $0,000(p<0,010)$.
\end{abstract}

\section{Keywords: Friendship, Friendship Quality, Communication, Communication Media}

Kualitas persahabatan pada masa remaja berbeda dengan kualitas persahabatan pada masa anak-anak. Hal ini disebabkan oleh pengalaman kehidupan sosial yang berbeda (Sprinthall \& Collins, 1995). Buhrmester (Santrock, 2003) menyatakan bahwa kualitas persahabatan lebih dihayati pada masa remaja dibandingkan pada masa anak-anak. Remaja dengan teman-teman yang tidak begitu dekat atau tidak mempunyai sahabat dekat sama sekali melaporkan bahwa perasaannya lebih sepi, depresi dan tegang, dan memiliki harga diri yang lebih rendah dibandingkan dengan remaja yang memiliki kualitas persahabatan yang lebih akrab. Hasil penelitian Sullivan (Santrock, 2003) menunjukkan bahwa ada peningkatan yang dramatis dalam kadar kepentingan secara psikologis dan keakraban antar teman dekat pada masa awal remaja dibanding masa anak-anak.

Kualitas persahabatan sebagai sebuah hubungan sosial ditentukan oleh kualitas komunikasi. De Vito (1997) menyatakan bahwa salah satu tujuan komunikasi adalah untuk berhubungan, di mana komunikasi dilakukan untuk membina dan memelihara hubungan sosial. Parks (Chan \& Cheng,
2004) menyatakan bahwa variasi topik pembicaraan, keterbukaan, dan penggunaan kata-kata yang hanya diketahui oleh dua individu yang saling berkomunikasi berkaitan dengan kualitas komunikasi. Individu cenderung lebih terbuka mengungkapkan informasi penting dan pribadi seiring berjalannya hubungan. Dengan demikian, komunikasi akan berkembang selama persahabatan berlangsung yang kemudian dapat mempengaruhi kualitas persahabatan.

Sebagai dampak perkembangan teknologi, komunikasi di samping dilakukan secara langsung, komunikasi juga dilakukan menggunakan media seperti telepon genggam, dan internet. Tidak hanya untuk mengirim pesan singkat dan membuat panggilan, telepon genggam saat ini telah dilengkapi fitur-fitur yang memungkinkan penggunanya untuk mengakses Internet. Jumlah pengguna telepon genggam di Indonesia hingga Juni 2010 diperkirakan mencapai 180 juta pelanggan, atau $80 \%$ dari total penduduk Indonesia (Harian Berita, 2010). Ditemukan fakta lain bahwa pengguna telepon genggam remaja di Indonesia meningkat hampir empat kali lipat 
lebih dalam lima tahun terakhir. Survei dari Nielsen Company menunjukkan bahwa penetrasi telepon genggam di kalangan remaja usia 15-19 tahun pada 2005 hanya $18 \%$, sedangkan saat ini mencapai $70 \%$ (Suprapto \& Purborini, 2011).

Hasil survei mengenai penggunaan media komunikasi yang dilakukan pada tanggal 14 April 2011 pada sejumlah mahasiswa Program Studi Psikologi, Fakultas Psikologi dan Ilmu Sosial Budaya, Universitas Islam Indonesia menunjukkan bahwa selain berkomunikasi secara langsung, mahasiswa juga banyak menggunakan media sebagai alternatif berkomunikasi dengan sabahatnya. Penggunaan media tersebut antara lain SMS (Short Message Service), BBM (BlackBerry Messenger), situs jejaring sosial (Facebook dan Twitter), fasilitas chatting lewat internet (Yahoo! Messenger), telepon, dan e-mail. Seorang responden (wawancara pada 19 April 2011) menyatakan bahwa komunikasi dengan sahabat dapat dilakukan dalam bentuk apa saja, namun ia lebih merasa dekat jika bisa berbicara secara langsung (tatap muka). Sedangkan responden lain menyatakan hal yang sedikit berbeda, di mana ia termasuk sering berkomunikasi dengan sahabat dengan mengirim SMS (melalui media) karena selalu ingin berbicara atau berbagi apa saja yang baru dialaminya dengan sahabat.

Mahasiswa sedang berada pada masa remaja akhir sampai masa dewasa awal, di mana hubungan dekat seperti persahabatan menjadi hal yang penting dalam perkembangan sosial dan kesejahteraan dirinya. Kualitas persahabatan ini menarik untuk diteliti di mana dalam proses sosialisasi, hubungan persahabatan merupakan sumber dukungan yang penting. Persahabatan juga merupakan pemenuhan kebutuhan akan hubungan dekat dan kebersamaan. Penelitian ini diharapkan dapat menunjukkan bagaimana kualitas persahabatan mahasiswa yang dibedakan melalui media komunikasi, di mana komunikasi yang dilakukan mahasiswa tidak hanya dilakukan secara tatap muka, namun juga dilakukan melalui media. Dengan adanya perbedaan tersebut hipotesis penelitian yang diajukan ialah adanya perbedaan kualitas persahabatan ditinjau dari media komunikasi.

\section{METODE PENELITIAN}

\section{Responden Penelitian}

Responden penelitian ini adalah mahasiswa S-1 program studi Psikologi, Fakultas Psikologi dan Ilmu Sosial Budaya, Universitas Islam Indonesia, laki-laki dan perempuan, berusia antara 17-24 tahun, memiliki lebih dari satu sahabat dekat, dan tidak hanya secara langsung berkomunikasi dengan sahabatnya, tetapi juga menggunakan media pesan teks, seperti SMS (Short Message Service), BBM (BlackBerry Messenger), Twitter, Facebook chat, dan Yahoo! Messenger.

\section{Metode Pengumpulan Data}

Penelitian ini menggunakan skala kualitas persahabatan yang disusun berdasarkan enam aspek kualitas persahabatan dari Asher dan Parker (1993). Skala ini akan mengukur dua kualitas persahabatan baik melalui tatap muka (berkomunikasi secara langsung) maupun melalui media pesan teks (berkomunikasi melalui media).

Adpun aspek-aspek kualitas persahabatan menurut Asher dan Parker (1993) terdiri atas:

a. Pengakuan dan pengertian (validation and caring)

Tingkat di mana karakteristik hubungan persahabatan ditandai dengan kepedulian, dukungan dan minat.

b. Konflik dan pengkhianatan (conflict and betrayal)

Hubungan persahabatan ditandai dengan adanya argumen, ketidaksetujuan, kekesalan, dan ketidakpercayaan.

c. B e rkaw a n a n rekreas i (companionship and recreation)

Tingkat di mana hubungan persahabatan ditandai dengan menghabiskan waktu untuk bersenangsenang bersama.

d. Pertolongan dan bimbingan (help and 
guidance)

Tingkat di mana individu berusaha membantu sahabatnya pada pekerjaan sehari-hari maupun pada sesuatu hal yang menantang.

e. Pertukaran keakraban (intimate exchange)

Tingkat di mana hubungan persahabatan ditandai dengan keterbukaan mengenai informasi pribadi dan perasaan.

f. Pemecahan masalah (conflict resolution)

Tingkat di mana ketidaksetujuan dalan hubungan persahabatan diselesaikan secara efisien dan adil.

\section{Metode Analisis Data}

Untuk mengetahui perbedaan kualitas persahabatan antara secara tatap muka dan melalui media, data akan dianalisis menggunakan Paired Samples Test.

\section{HASIL PENELITIAN}

\section{Deskripsi Responden Penelitian}

Tabel 1

Kategorisasi Responden Berdasarkan Jenis Kelamin Sahabat pada Kedua Data Kualitas Persahabatan $(\mathrm{N}=91)$

\begin{tabular}{|c|c|c|c|c|c|c|c|c|c|}
\hline \multirow{6}{*}{ 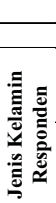 } & & \multicolumn{8}{|c|}{ Kualitas Persahabatan } \\
\hline & & \multicolumn{4}{|c|}{ Tatap Muka } & \multicolumn{4}{|c|}{ Melalui Media } \\
\hline & & \multicolumn{2}{|c|}{ laki-laki } & \multicolumn{2}{|c|}{ Perempuan } & \multicolumn{2}{|c|}{ laki-laki } & \multicolumn{2}{|c|}{ Perempuan } \\
\hline & & $\begin{array}{c}\text { Jumla } \\
\text { h }\end{array}$ & $\%$ & $\begin{array}{c}\text { jumla } \\
\text { h }\end{array}$ & $\%$ & $\begin{array}{c}\text { Jumla } \\
\text { h }\end{array}$ & $\%$ & $\begin{array}{c}\text { Juml } \\
\text { ah }\end{array}$ & $\%$ \\
\hline & laki-laki & 18 & $\begin{array}{r}19,7 \\
8\end{array}$ & 8 & 8,80 & 13 & $\begin{array}{r}14,2 \\
9\end{array}$ & 13 & $\begin{array}{r}14,2 \\
9\end{array}$ \\
\hline & $\begin{array}{l}\text { perempua } \\
\text { n }\end{array}$ & 6 & 6,59 & 59 & $\begin{array}{r}64,8 \\
3\end{array}$ & 18 & $\begin{array}{r}19,7 \\
8\end{array}$ & 47 & $\begin{array}{r}51,6 \\
4\end{array}$ \\
\hline
\end{tabular}

\section{Deskripsi Data Penelitian}

Tabel 2

Deskripsi Statistik Perbandingan Skor Individu pada kedua Skala Kualitas Persahabatan

\begin{tabular}{lccccccc}
\hline Variabel & \multicolumn{3}{c}{ Hipotetik } & \multicolumn{3}{c}{ Empirik } \\
\hline Kualitas Persahabatan & Min & Max & Mean & Min & Max & Mean & SD \\
\hline Tatap Muka & 53 & 212 & 132,5 & 131 & 208 & 171,5 & 16,87 \\
& & & & & & 2 & \\
Melalui Media & 51 & 204 & 127,5 & 131 & 195 & 160,0 & 16,19 \\
& & & & & & 9 & \\
\hline
\end{tabular}

Tabel 3

Kategorisasi Kualitas Persahabatan Tatap Muka

\begin{tabular}{lccc}
\hline Kategori & Nilai & Jumlah & Presentase \\
\hline Rendah & $\mathrm{X}<154,65$ & 11 & $12,09 \%$ \\
Sedang & $154,65<\mathrm{X} \leq 188,39$ & 64 & $70,33 \%$ \\
Tinggi & $188,39 \leq \mathrm{X}$ & 16 & $17,58 \%$ \\
Total & & 91 & $100,00 \%$ \\
\hline
\end{tabular}

Berdasarkan data kategorisasi di atas maka dapat dilihat sebagian besar responden penelitian berada pada kategori sedang $(70,33 \%)$, di mana rentang skor kualitas persahabatannya berkisar antara $154,65<\mathrm{X}$ $\leq 188,39$.

Tabel 4

Kategorisasi Kualitas Persahabatan Melalui Media

\begin{tabular}{lccc}
\hline Kategori & Nilai & Jumlah & Presentase \\
\hline Rendah & $\mathrm{X}<143,90$ & 13 & $14,29 \%$ \\
\hline Sedang & $143,90<\mathrm{X} \leq 176,28$ & 60 & $65,93 \%$ \\
\hline Tinggi & $176,28 \leq \mathrm{X}$ & 18 & $19,78 \%$ \\
\hline Total & & 91 & $100,00 \%$ \\
\hline
\end{tabular}

Berdasarkan data kategorisasi di atas maka dapat dilihat bahwa sebagian besar responden penelitian berada pada kategori sedang $(65,93 \%)$, di mana rentang skor kualitas persahabatannya berkisar antara $143,90<\mathrm{X} \leq 176,28$.

\section{Hasil Uji Normalitas}

Uji normalitas dilakukan untuk mengetahui penyebaran data penelitian apakah terdistribusi secara normal dalam sebuah populasi. Pengujian normalitas dilakukan dengan teknik One-Sample Kolmogorov-Smirnov Test. Kaidah yang digunakan apabila $\mathrm{p}>0,05$ maka sebaran data normal, namun jika $\mathrm{p}<0,05$ maka sebaran data tidak normal.

\section{Hasil Uji Hipotesis}

Hasil analisis menununjukkan ada perbedaan yang sangat signifikan antara kualitas persahabatan tatap muka dengan kualitas persahabatan melalui media $(\mathrm{t}(91)=$ 7,055, $\mathrm{p}<0,01)$. Kualitas persahabatan secara tatap muka $($ Mean $=171,52, \mathrm{SD}=$ 16.87) lebih baik dari kualitas persahatan melalui media $($ Mean $=160,10, S D=16.19)$.

Tabel 5 berikut adalah laporan hasil analisis Paired Sample Test per aspek (enam aspek dari Asher \& Parker).

Tabel 5

Hasil Uji Beda Kualiatas Persahabatan per Aspek

\begin{tabular}{ccccccc}
\hline \multirow{2}{*}{ Aspek } & \multicolumn{2}{c}{ Mean } & & & \\
\cline { 2 - 6 } & $\mathbf{I}$ & II & $\mathbf{T}$ & $\mathbf{P}$ & Kesimpulan & Analisis \\
\hline 1 & 29,74 & 29,64 & 0,32 & 0,74 & $\mathrm{p}>0,05$ & Tidak ada perbedaan \\
\hline 2 & 29,13 & 29,09 & 0,08 & 0,93 & $\mathrm{p}>0,05$ & Tidak ada perbedaan \\
\hline 3 & 25,69 & 17,06 & 21,26 & 0,00 & $\mathrm{p}<0,05$ & Ada perbedaan \\
\hline 4 & 29,62 & 25,09 & 14,42 & 0,00 & $\mathrm{p}<0,05$ & Ada perbedaan \\
\hline 5 & 38,00 & 33,75 & 8,48 & 0,00 & $\mathrm{p}<0,05$ & Ada perbedaan \\
\hline 6 & 19,31 & 25,42 & $-21,70$ & 0,00 & $\mathrm{p}<0,05$ & Ada perbedaan \\
\hline
\end{tabular}


Keterangan:

1. Pengakuan dan pengertian (validation and caring)

2. Konflik dan pengkhianatan (conflict and betrayal)

3. B e r kawa n a n rekreas i (companionship and recreation)

4. Pertolongan dan bimbingan (help and guidance)

5. Pertukaran keakraban (intimate exchange)

6. Pemecahan masalah (conflict resolution)

\section{PEMBAHASAN}

Penelitian ini bertujuan untuk menguji hipotesis mengenai adanya perbedaan kualitas persahabatan mahasiswa ditinjau dari media komunikasi. Berdasarkan hasil analisis data disimpulkan bahwa hipotesis diterima, yaitu adanya perbedaan yang sangat signifikan antara kualitas persahabatan tatap muka dengan kualitas persahabatan melalui media. Media komunikasi yang dibandingkan adalah tanpa media (tatap muka) dan melalui media pesan teks (SMS, BBM, Facebook chat, Twitter, dan Yahoo! Messenger). Pembahasan mengenai perbedaan kualitas persahabatan di antara kedua jenis media komunikasi dapat dilihat lebih mendalam dari hasil analisis tambahan perbedaan kualitas persahabatan berdasarkan enam aspek dari Asher dan Parker (1993). Aspek kualitas persahabatan pada data kualitas persahabatan tatap muka dibandingkan dengan aspek kualitas persahabatan pada data kualitas persahabatan melalui media memperlihatkan baik adanya perbedaan maupun tidak adanya perbedaan.

Pada aspek pertama, pengakuan dan pengertian, tidak ditemukan perbedaan $(\mathrm{t}(91)=0,32, \mathrm{p}<0,05)$ dan perbedaan nilai mean yang kecil, yaitu sebesar 0,1 (skor mean pada data kualitas persahabatan tatap muka $=29,74$; skor mean pada data kualitas persahabatan melalui media $=29,64$ ). Selanjutnya, aspek kedua yaitu konflik dan pengkhianatan, juga tidak ditemukan perbedaan $(\mathrm{t}(91)=0,08, \mathrm{p}<0,05)$ dan perbedaan nilai mean yang kecil yaitu sebesar 0,04 (skor mean pada data kualitas persahabatan tatap muka $=29,13$; skor mean pada data kualitas persahabatan melalui media $=29,09$ ).

Sisa aspek kualitas persahabatan yang lain ditemukan perbedaan, yaitu berkawan dan rekreasi $(\mathrm{t}(91)=21,26, \mathrm{p}<0,05)$, pertolongan dan bimbingan $(\mathrm{t}(91)=14,42, \mathrm{p}$ $<0,05)$, pertukaran keakraban $(\mathrm{t}(91)=8,48, \mathrm{p}$ $<0,05)$, dan pemecahan masalah seluruhnya $(\mathrm{t}(91)=-21,70, \mathrm{p}<0,05)$. Keempat hasil ini yang memperkuat perbedaan antara kualitas persahabatan tatap muka dengan kualitas persahabatan melalui media. Temuan yang menarik dari hasil analisis tambahan ini adalah pada aspek pemecahan masalah. Skor mean pada data kualitas persahabatan melalui media $(25,42)$ tampak lebih besar dari skor mean pada data kualitas persahabatan tatap muka $(19,31)$. Hal ini menunjukkan bahwa pemecahan masalah dapat diselesaikan lebih efektif melalui media, sedangkan berkawan dan rekreasi, pertolongan dan bimbingan, dan pertukaran keakraban lebih berkesan jika dilakukan secara langsung. Pemecahan masalah dapat diselesaikan lebih efektif melalui media bisa terjadi karena isi pesan yang disampaikan melalui media dapat disusun sebaik mungkin tata bahasa dan maksudnya sehingga menimbulkan kesan yang lebih baik dibandingkan bertemu langsung kemudian dalam penyelesaian masalah diikuti dengan adu argumen dan cemooh.

Kualitas persahabatan yang berbeda antara kualitas persahabatan tatap muka dengan kualitas persahabatan melalui media ini juga didukung oleh hasil penelitian dari Parks dan Roberts mengenai kualitas hubungan persahabatan online dan offline (Chan \& Cheng, 2004). Persahabatan online adalah hubungan dengan sahabat yang dikenal lewat Internet dan dalam berinteraksi juga selalu melalui Internet, sedangkan persahabatan offline adalah hubungan dengan sahabat yang dikenal bukan dari Internet dan dalam berinteraksi selalu tatap muka. Hasil penelitiannya menunjukkan bahwa kualitas hubungan persahabatan online secara signifikan lebih rendah dibandingkan dengan kualitas hubungan 
persahabatan offline dalam hal ketergantungan, pemahaman, komitmen dan kesamaan orang yang dikenal.

Miller dan Steinberg (Tubbs \& Moss, 2001) mengungkapkan bahwa terdapat beberapa konsep untuk membedakan hubungan yang berkualitas tinggi dengan yang berkualitas rendah, yaitu (1) bahwa dalam hubungan berkualitas tinggi, informasi tentang orang lain lebih bersifat psikologis daripada bersifat kultural dan sosiologi, (2) bahwa aturan-aturan dalam hubungan ini lebih banyak dikembangkan oleh kedua orang yang terlibat di dalamnya daripada diatur oleh tradisi, (3) peranan dalam hubungan antarpersona lebih ditentukan oleh karakter pribadi daripada oleh situasi, dan (4) bahwa hubungan berkualitas tinggi lebih menekankan pada pilihan perseorangan daripada pilihan kelompok. Pilihan perseorangan, informasi psikologis, dan penyingkapan diri merupakan beberapa variabel yang memengaruhi kualitas hubungan. Sehingga meskipun kualitas persahabatan melalui media lebih rendah dibandingkan dengan kualitas persahabatan tatap muka, tetap ada faktor lain yang dapat dijadikan acuan dalam membandingkan kualitas hubungan persahabatan.

Kelemahan dalam penelitian ini antara lain peneliti tidak mengontrol apakah benar pada sahabat yang berkomunikasi melalui media, tidak dilakukan komunikasi secara tatap muka. Alasan berkomunikasi melalui media bisa jadi bukan merupakan alternatif pilihan dalam berkomunikasi dengan sahabatnya, melainkan responden tidak dapat berinteraksi secara langsung dengan sahabatnya itu. Kelemahan lain adalah meskipun di dalam alat ukur peneliti menanyakan komunikasi yang mana di antara tatap muka dengan komunikasi melalui media yang lebih nyaman dilakukan oleh responden, namun data tersebut tidak diolah lebih lanjut. Dalam penyusunan alat ukur, pada aspek konflik dan pengkhianatan butir soalnya mengindikasikan jika dalam hubungan persahabatan terjadi konflik, maka kualitas persahabatan akan menurun, sedangkan konflik itu sendiri merupakan komponen dari kualitas persahabatan sehingga alat ukur masih perlu diperbaiki. Kelemahan terakhir yaitu peneliti kurang jelas saat memberikan prosedur pengisian alat ukur dan meminta bantuan responden di waktu yang kurang tepat (saat kelas akan berakhir) sehingga dalam pengisian alat ukur banyak yang gugur karena pengisian tidak lengkap.

\section{Simpulan \\ SIMPULAN DAN SARAN}

Berdasarkan hasil analisis data dan pembahasan yang telah dilakukan, maka dapat disimpulkan bahwa ada perbedaan kualitas persahabatan yang sangat signifikan antara kualitas persahabatan dengan sahabat yang berkomunikasi secara tatap muka dengan sahabat yang berkomunikasi melalui media pesan teks.

\section{Saran}

Bagi penelitian selanjutnya, peneliti dapat melakukannya pada responden yang berbeda dengan responden dalam penelitian ini, misalnya pada remaja awal dan pada masa dewasa. Selain itu, dalam penelitian selanjutnya dapat memperbanyak responden penelitian. Penelitian lain yang juga bisa dilakukan yaitu membedakan kualitas persahabatan antara individu yang nyaman berkomunikasi secara langsung (tatap muka) dengan individu yang nyaman berkomunikasi melalui media dan jika akan menggunakan alat ukur yang telah disusun dalam penelitian ini, maka masih perlu dilakukan pengembangan dan perbaikan alat ukur.

\section{DAFTAR PUSTAKA}

Asher, S.R \& Parker, J. G. 1993. Friendship and Friendship Quality in Middle Childhood: Links With Peer Group Acceptance and Feelings of Loneliness and Social Dissatisfaction. Journal of Developmental Psychology, 29 (4), 611-621. Diunduh pada 13 April $\begin{array}{lllll}2 & 0 & 1 & 1 & \mathrm{~d}\end{array}$ http://www.psych.utah.edu/classes/2 007_fall/3220_001/readings/parker. pdf 
Berndt, T. J. 2002. Friendship Quality and Social Development. American Psychological Society, 11(1), 7-10. Diunduh pada 24 Maret 2011 dari http://www1.psych.purdue.edu/ ber ndt/Friendship\%20quality\%20and\% 20social\%20development.pdf

Cangara, H. 2008. Pengantar Ilmu Komunikasi. Edisi Revisi. Jakarta: Raja Grafindo Persada.

Chan, D. K.S. \& Cheng, G. H. L. 2004. A Comparison of offline and online friendship qualities at different stages of relationship development. Journal of Social and Personal Relationships, 21(3), 305-320. Diunduh pada 2 Mei 2011 dari http://www.kirkarts.com/wiki/image s/1/14/Offline-online_rel.pdf

De Vito, J.A. 1997. Komunikasi Antarmanusia: Kuliah Dasar. Edisi kelima. Jakarta: Profesional Books.

Floyd, K. 2009. Interpersonal Communication: The Whole Story. New York: McGraw Hill Companies.
Harian Berita. 2010. Jumlah Pemakai Handphone di Indonesia. Diunduh d a r r i http://www.harianberita.com/jumlah - p e maka i - hand p ho n e - d i indonesia.html

Santrock, J.W. 2003. Adolescene: Perkembangan Remaja. Jakarta: Erlangga.

Sprinthall, N. A \& Collins, W. A. 1995. Adolescent Psychology: A Developmental View. New York: McGraw Hill Inc.

Suprapto, H \& Purborini. 2011. Nielsen: Remaja Pengguna Ponsel Melonjak. $\mathrm{D} \mathrm{i} \mathrm{n} \mathrm{d} \mathrm{u} \mathrm{h} \quad \mathrm{d} \mathrm{a} \mathrm{r}$ i http://teknologi.vivanews.com/news / read/203546-nielsen-- 70 - pengguna-ponsel-remaja

Tubbs, S. L. \& Moss, S. 2001. Human Communication. Konteks-konteks Komunikasi. B andung: Rosdakarya

Vardiansyah, D. 2004. Pengantar Ilmu Komunikasi. Bogor: Ghalia Indonesia. 